\title{
DESIGN OF SHOOTING SCORE RECORDING INFORMATION SYSTEM BASED ON IMAGE PROCESSING
}

\author{
Choirur Rozikin, Fifin Kurnianto, Ahmadi, Mohammad Syaifi \\ D-3 Teknik Informatika, Sekolah Tinggi Teknologi Angkatan Laut, \\ www.sttal.ac.id
}

\begin{abstract}
Image processing shooter-based Information System is very useful for STTAL, which has a vision to become a center for the development of defense science and technology in the field of military, maritime and reliable seas at the regional level in realizing the independence of the main weapons system.

STTAL has the mission of organizing higher education programs to produce human resources with Indonesian character and personality, based on science and technology that are of high quality and relevant to the defense needs of the military, maritime and marine departures. In carrying out its duties as an educational institution, STTAL also carries out its obligations as the Indonesian National Army. So with that STTAL often hold short barrel or pistol shooting exercises. In a series of short barrel or pistol shooting activities, each process of recording values is still carried out visually, that is by looking directly at the target and counting manually, so that it takes a lot of members of the shooting committee and takes a long time in recording values. We design a application of image processing information system based shots which can be used in shooting exercises to facilitate all members in carrying out shooting exercises at STTAL. In this application the shooter can see firsthand the value of the shot obtained so that it can concentrate fully in carrying out a shooting exercise. In this application also makes it easy for the head of the shooting committee to make a report to the commander quickly and accurately, for the commander to see first hand the results of the shooting practice and it's easy to take a decision on shooting practice.
\end{abstract}

Keywords: Value Marker, Shooting, Image Process.

\section{INTRODUCTION}

The Naval College of Technology (STTAL) is one of the navy's ranks of cities. STTAL was established on August 24, 1966. STTAL has a vision to become a center for the development of defense science and technology in the field of military, maritime and regional seas that are reliable at the regional level in realizing the independence of the main weapons system. STTAL has the mission of organizing higher education programs to produce human resources with Indonesian character and personality, based on science and technology that are of high quality and relevant to the defense needs of the military, maritime and marine departures. In carrying out its duties as an educational institution, STTAL also carries out its obligations as the Indonesian National Army. So with that STTAL often held short barrel shooting practice.

STTAL conducts shooting exercises per semester, short barrel shooting exercises are carried out by all officers, members of intelligence and pomal members for long barrels carried out by all non-commissioned and enlisted members. In the series of shooting activities both short and long barrel each process of recording values is still done visually, that is by looking directly at the target and counting manually. The manual assessment and calculation process requires a lot of time and is inefficient so the shooting practice is not optimal. The shooting value information system is needed to make it easier for the shooters to record and accumulate shot values, and also to find out the value of the shots from other shooters.

Based on the background of the problem above, then the problem can be formulated, namely how to design and build an image processing system based on image processing at STTAL?

The purpose of this research is to design and build an image recording system based on image processing STTAL. With this system can help the process of recording and 
accumulating the results of all shooting activities and can avoid mistakes in recording the value of the shot so that the information provided can easily be accepted and understood.

The benefits of this research are as follows:

a. For STTAL members:

1) Simplify the process of recording shot values.

2) Shorten the process time for recording the shot value.

3) Facilitate reporting of shots to the Commander of STTAL.

b. For STTAL Commander:

1) Easily find out data on the value of shots of all personnel.

2) It is easy to supervise personnel who carry out shooting activities.

3) Easy in making decisions / policies that are appropriate based on the reports received.

c. For STTAL Units:

1) It's easier to recap the shot value of all members.

2) Easy to do reporting to the commander.

The focus of this study are as follows:

a. Data for trials taken at STTAL.

b. The process of shooting and image processing using a webcam camera that functions to read and assess data received from the camera.

c. Cannot detect shots in the same hole.

\subsection{Image Processing}

Image or Image is another term of image, which is visual information. An image is obtained by capturing the strength of the light reflected by the object. When the light source illuminates the object, the object reflects back some of the light. This reflection is captured by optical sensing devices, such as the human eye, camera, scanner and so on. The shadow of the object will be recorded according to the intensity of the reflected light. When an optical device that records the reflection of light is a digital machine, such as a digital camera, the resulting image is a digital image. In digital images, the continuity of the intensity of the light is quantized according to the resolution of the recording device.

The image is a 2-dimensional intensity function $f(x, y)$, where $x$ and $y$ are special coordinates and $f$ at the point $(x, y)$ is the brightness level of an image at a point. Digital image is an image of $f(x, y)$ that has been digitalized both the area coordinates and the brightness level. The $f$ value in the coordinates $(x, y)$ indicates the brightness or grayness level of the image at that point.

Digital imagery is a representation of a two-dimensional image as a collection of digital values called image elements or pixels. Pixels are the smallest elements that make up the image and contain values that represent the brightness of a color at a particular point. Generally digital images are rectangular or square (in some imaging systems there are also hexagon shaped) which have a certain width and height. This size is usually expressed in terms of pixels so that the image size is always round. Each pixel has coordinates according to their position in the image. These coordinates are usually expressed in positive integers, which can start from 0 or 1 depending on the system used. Each pixel also has a value in the form of a digital number that represents the information represented by that pixel. The format of digital image data is closely related to color. In most cases, especially for the purpose of visual appearance, digital data values represent the colors of the processed image. The most widely used digital image formats are Binary Image (monochrome), Gray Scale Image, True Color Image, and Indexed Color Image.

Image processing is a processing process whose input is image. The output can be an image or a set of characteristics or parameters related to the image. The term digital image processing is generally defined as two-dimensional image processing with a computer. In a broader definition, digital image processing also includes all two-dimensional data. Digital images are rows of real and complex numbers that are represented by certain bits.

\subsection{Webcam Logitech C270}

Webcam is a combination of the words web and camera. Webcam itself is a term for real-time cameras (meaning current conditions) whose images can be accessed or viewed through the internet, instant messaging programs such as Yahoo Messenger, AOL Instant Messenger (AIM), Windows Live Messenger, and Skype, and others. The term "webcam" itself refers to the type of camera used for web-based service needs. The webcam itself is usually used for remote conferences or as a monitoring camera. 
Webcam is a peripheral in the form of a camera as an image taker / image and a microphone (optional) as a voice / audio receiver controlled by a computer or by a computer network. The picture taken by WebCam is displayed on the monitor screen, because it is controlled by a computer then there is an interface or port that is used to connect WebCam with acomputer or network. There are some people inerpret WebCam as Web pages + Camera, because by using WebCam to take video images can actually be uploaded directly when the computer that controls the internet connected.

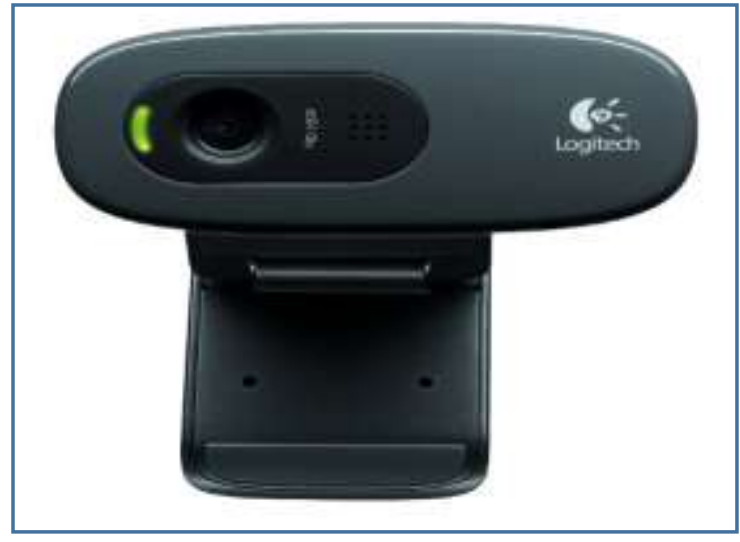

Figure 1. Webcam Logitech C270 (Source: Camera Logitech c270)

\subsection{USB connector}

USB is the abbreviation for Universal Serial Bus. USB is a technology that allows us to connect external devices (peripherals) such as scanners, printers, mice, keyboards (keyboards), data storage devices (zip drives), flash drives, digital cameras or other devices to our computers. USB strongly supports data transfer of 12 Mbps (million bits per second). Computers (PCs) currently, generally already have a USB port. Usually provided at least 2 ports. When compared with parallel ports and serial ports, the use of USB ports is easier to use.

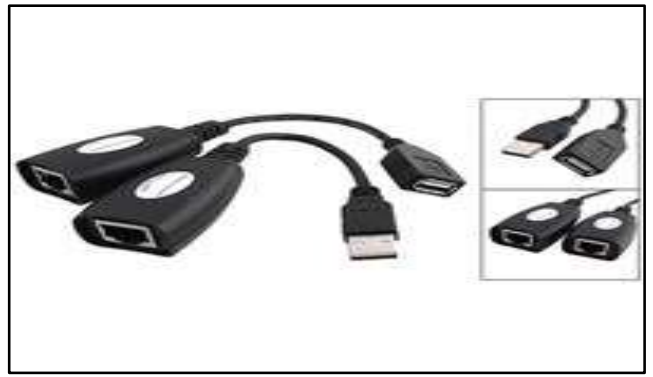

Figure USB Kabel LAN

(Source: USB RJ45 Extension adapter)

\subsection{Konektor RJ45}

RJ45 is an ethernet cable connector that mostly has a function as a connector on the LAN computer network (Local Area Network) topology and other network topologies.

$\mathrm{RJ}$ itself is an abbreviation of Registered Jack, which is a standard equipment in the network that regulates the installation of the connector head and cable sequence, which is used to connect 2 or more telecommunications equipment (Telephone Jack) or network equipment (Computer Networking). It is also a physical interface of a network, for telecommunications and data communication purposes. The RJ45 connector has a function to make it easy to change telephone or make it easy to move around and is easy to unplug without worrying about being electrocuted and connecting the LAN connector through a central network.

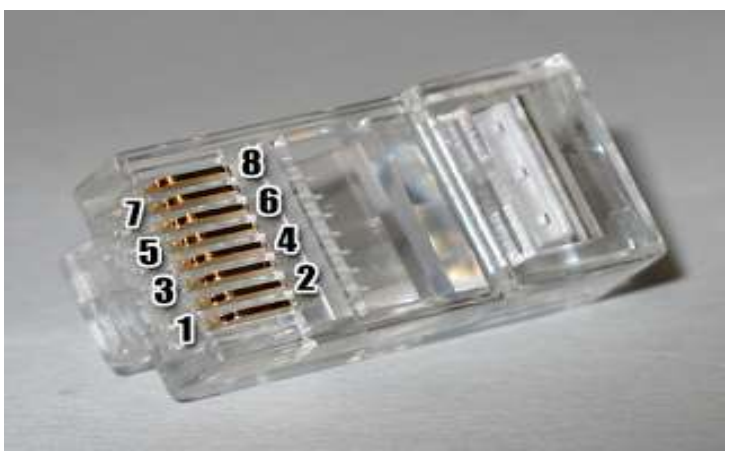

Figure 2. RJ45

\section{RESEARCH DESIGN}

The research design is a stage to provide an overview- of the system that will be created. Starting from analyzing the system is the stage of studying the existing system based on the results of a survey of existing problems. Then various survey data are processed to get a general picture of the results obtained. 


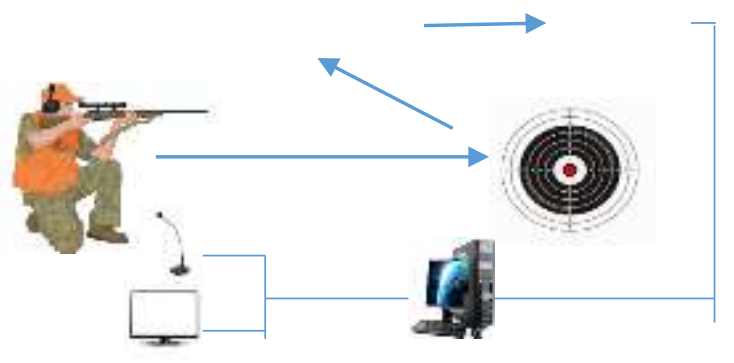

Figure System Description.

An overview of the system of a shooting target that has finished shooting will take a shot value through taking photos or pictures taken using the camera by the admin who is on the server by clicking the enter button on the keyboard and then the camera that is available in front of the target shooting do shooting shooting target value. then the image is processed by sending image data to a server (admin) and sending images or data received faster on the server (admin).

\subsection{Design}

Design is a process carried out on a project that we are working on, starting from a research design. In principle, good design and systematic can provide convenience in the manufacturing process to become an application system that really functions as it should. In the design of an information system for recording shots based on image processing consists of several designs, namely input / output design and form design.

Input / output design is a design in the image processing information system based on image processing, as a whole consisting of input and output designs.

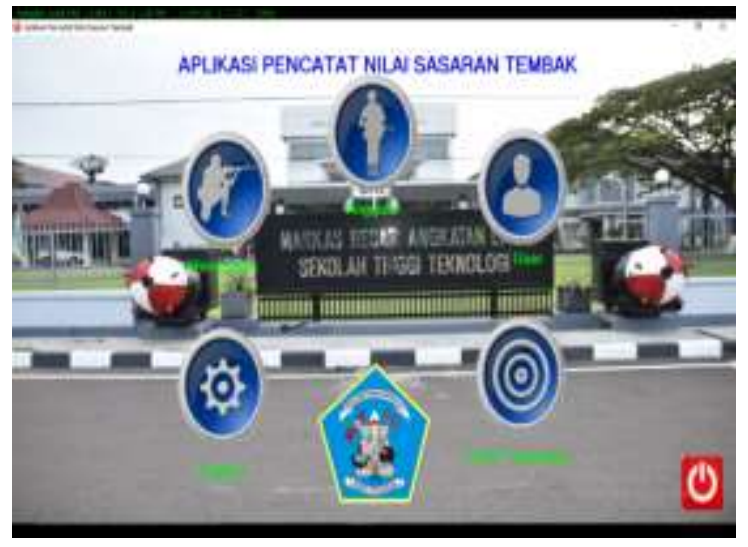

Figure Main Menu Design

\subsection{Testing}

The testing of the image processing system based on image processing is done with the aim to find out the capability of the system that has been built in carrying out several processes. The implementation of system testing is divided into two, namely testing the software and testing the hardware to determine the results of the design made.

\section{RESULTS AND DISCUSSION}

Results and discussion of computer reading distance testing to Webcam is the part that explains the results of Webcam reading reading test data that has been done. From testing the ability to read the webcam distance obtained test results that can be seen in the table. 
Table 1. Reading distance Computer to webcam

\begin{tabular}{|l|l|l|l|}
\hline No & $\begin{array}{c}\text { Jarak } \\
(\mathbf{m})\end{array}$ & Kondisi & \multicolumn{1}{|c|}{ Data nilai } \\
\hline $\mathbf{1 .}$ & 100 & Undetected & No Scoring \\
\hline $\mathbf{2 .}$ & 90 & Undetected & No Scoring \\
\hline $\mathbf{3 .}$ & 75 & Undetected & No Scoring \\
\hline $\mathbf{4 .}$ & 50 & Undetected & No Scoring \\
\hline $\mathbf{5 .}$ & 30 & Undetected & No Scoring \\
\hline $\mathbf{6 .}$ & 25 & Detected & Scoring \\
\hline $\mathbf{7 .}$ & 16 & Detected & Scoring \\
\hline $\mathbf{8 .}$ & 8 & Detected & Scoring \\
\hline $\mathbf{9 .}$ & 4 & Detected & Scoring \\
\hline $\mathbf{1 0 .}$ & 1 & Detected & Scoring \\
\hline
\end{tabular}

Based on the above table, it can be concluded that the ability to read the Webcam for a distance of 25 meters can still send values on the committee's computer and at a distance of 30 meters the Webcam cannot send the value data on the committee's computer. Testing the webcam reading distance is also influenced by the quality of the webcam.

The results and discussion of the Webcam reading distance testing to the target are the parts that explain the results of the Webcam reading distance testing data on the shot target that has been carried out. From testing the ability to read the Webcam against the target obtained test results can be seen in the table.

Table 2. Read webcam distance to target

Based on the table above, it can be concluded that the ability to read the webcam

\begin{tabular}{|l|l|l|l|}
\hline No & $\begin{array}{c}\text { Jarak } \\
(\mathrm{m})\end{array}$ & Kondisi & \multicolumn{1}{|c|}{ Data nilai } \\
\hline 1. & 5 & Undetected & No Scoring \\
\hline 2. & 4 & Undetected & No Scoring \\
\hline 3. & 3 & Undetected & No Scoring \\
\hline 4. & 2 & Detected & Scoring \\
\hline 5. & 1 & Detected & Scoring \\
\hline
\end{tabular}

distance to the target shooting hole for a distance of 2 meters can still be detected on the camera and can send values on the committee's computer and at a distance of 3 meters Webcam cannot detect a shot hole on the target so that it cannot send data value on the committee's computer. Testing the reading distance of the webcam is also influenced by the quality of the webcam, the better the camera that is used the better the camera will be taken on the target image.

\section{CONCLUSION AND RECOMENDATION \\ 4.1. Conclusion}

Based on the results of tests that have been carried out on the design and construction of an image processing shooter-based information recording system, the following conclusions are obtained:

a. Can display data on the value of shots.

b. Can display firing personnel data.

c. Can carry out the process of finding data on the shooter personnel according to known criteria, namely name and NRP.

d. Target firing can be detected by webcams with a maximum distance of 2 meters and send data a maximum distance of 25 meters.

\subsection{Recomendation} are as follows:

Suggestions for system development a. This system can be made wirelessly.

b. In this system as a trigger the trigger for a shot can be from the mechanism of the weapon or from a pressure from the field of fire.

In this system the positioning of the camera has been made patent so it does not change the precision of an image. 


\section{References}

Darma Putra. (2010).TeoriPengolahan citra digital. Yogyakarta: Andi.

Mustakini,Jogiyanto HM.(2009). Sistem Teknologi Informasi (Edisi III).

Yogyakarta: Andi.

Mustakini,Jogiyanto Hartono. (2009). Teknologi Informasi (Edisi III).

Yogyakarta: Andi

Sutanta, Edhy. (2011). Basis Data dalam Tinjauan Konseptual. Yogyakarta: Andi.

T. Sutoyo. (2009).TeoriPengolahan citra digital. Yogyakarta: Andi.

Wilshusen, G.C. (2005). Information Security : Radio Frequency Identification Technology in the Federal Government, United Stated Government Accountability Office, Washington D.C. Retrieved July, 22, 2016, from http://www.gao.gov/new. items/d05551.pdf .
Sumber dari internet

Wikipedia. (2017). RJ45 Retrevied November, 2017, from https://id.wikipedia.org/wiki/RJ45.

Yonatan, Santoso. (2009). Penerapan kamera Web sebagai pendeteksi. Retrevied Oktober, 2017 from

portalgaruda.org/article.php?article

=PENERAPANKAMERAWEBSEBAGAIPEND

ETEKSIGERAKAN.com. 